University of Nebraska - Lincoln

DigitalCommons@University of Nebraska - Lincoln

Faculty Publications - Textiles, Merchandising and Fashion Design

Textiles, Merchandising and Fashion Design,

Department of

2013

Soy proteins as environmentally friendly sizing agents to replace poly(vinyl alcohol)

\author{
Lihong Chen \\ Donghua University, Shanghai, China \\ Narendra Reddy \\ University of Nebraska - Lincoln, nreddy3@unl.edu \\ Yiqi Yang \\ University of Nebraska-Lincoln, yyang2@unl.edu
}

Follow this and additional works at: https://digitalcommons.unl.edu/textiles_facpub

Chen, Lihong; Reddy, Narendra; and Yang, Yiqi, "Soy proteins as environmentally friendly sizing agents to replace poly(vinyl alcohol)" (2013). Faculty Publications - Textiles, Merchandising and Fashion Design. 30. https://digitalcommons.unl.edu/textiles_facpub/30

This Article is brought to you for free and open access by the Textiles, Merchandising and Fashion Design, Department of at DigitalCommons@University of Nebraska - Lincoln. It has been accepted for inclusion in Faculty Publications - Textiles, Merchandising and Fashion Design by an authorized administrator of DigitalCommons@University of Nebraska - Lincoln. 


\title{
Soy proteins as environmentally friendly sizing agents to replace poly(vinyl alcohol)
}

\author{
Lihong Chen, ${ }^{1,2}$ Narendra Reddy, ${ }^{2}$ and Yiqi Yang ${ }^{1,2,3,4}$ \\ 1. Key Laboratory of Science and Technology of Eco-Textiles, Ministry of Education, \\ Donghua University, Shanghai, China, 200051 \\ 2. Department of Textiles, Merchandising, \& Fashion Design, University of Nebraska-Lincoln, \\ 234, HECO Building, East Campus, Lincoln, NE 68583-0802, USA \\ 3. Department of Biological Systems Engineering, University of Nebraska-Lincoln, \\ 234, HECO Building, East Campus, Lincoln, NE 68583-0802, USA \\ 4. Nebraska Center for Materials and Nanoscience, University of Nebraska-Lincoln, \\ 234, HECO Building, East Campus, Lincoln, NE 68583-0802, USA \\ Corresponding author - Yiqi Yang, email yyang2@unl.edu
}

\begin{abstract}
An environmentally friendly and inexpensive substitute to the widely used poly(vinyl alcohol) (PVA) has been developed from soy proteins for textile warp sizing. Textile processing is the major source of industrial water pollution across the world, and sizing and desizing operations account for nearly $30 \%$ of the water consumed in a textile plant. PVA is one of the most common sizing agents used for synthetic fibers and their blends due to PVA's easy water solubility and ability to provide desired sizing performance. However, PVA does not degrade and is a major contributor to pollution in textile effluent treatment plants. Although considerable efforts have been made to replace PVA with biodegradable sizing materials, the performance properties provided by PVA on synthetic fibers and their blends have been unmatched so far. Soy proteins are inexpensive, biodegradable, and have been widely studied for potential use in food packaging, as resins and adhesives. In this research, the potential of using soy proteins as textile sizing agents to replace PVA was studied. Polyester and polyester/cotton rovings, yarns, and fabrics sized with soy protein showed a considerably better improvement in strength and abrasion resistance compared to commercially available PVA-based size. Soy protein size had a 5-day biochemical oxygen demand / chemical oxygen demand ratio of 0.57 compared to 0.01 for PVA indicating that soy protein sizes were easily biodegradable in activated sludge. The total and ammo-
\end{abstract}

nia nitrogen released from the proteins also did not adversely impact the biodegradability. Good sizing performance and easy biodegradability demonstrate that soy protein-based sizes have potential to replace PVA-based sizes leading to substantial benefits to the textile industry and the environment.

Keywords: sizing, poly(vinyl alcohol), biodegradation, proteins, ammonia, cohesion

\section{Introduction}

Textile production consumes considerable amounts of water and chemicals and the textile industry is a major contributor to water pollution and toxic discharges across the world. Producing a kilogram of fabric is estimated to consume about 600-1,000 kilogram of water during the preparation, dyeing, and finishing stages depending on the type of fabric made and processes used. A significant proportion of the dyes and chemicals used for textiles which are released into effluents are reportedly hazardous to the environment (Bisschops and Spanjers 2003). Among the various textile manufacturing stages, sizing is a critical process of imparting additional protection to warp yarns to withstand the abrasive forces during weaving. The protection to yarns is imparted by coating the yarns with chemicals called sizing agents/size. Starch and starch derivatives, car- 
boxymethyl cellulose, and synthetic polymers such as poly(vinyl alcohol) (PVA) have traditionally been the most widely used sizing chemicals (Cacho 1980; Cai et al. 2003; Du et al. 2007). In addition to the primary ingredient, sizing chemicals contain many other additives such as waxes and lubricants, softeners, emulsifiers, and finishing and wetting agents. Starch and starch derivatives are mainly used for cotton and cotton blends and PVA is mainly used for synthetic fibers and their blends. A size is evaluated based on its performance during weaving, ability to be removed (desized) after weaving, cost of the chemical, and biodegradability. A good size should decrease the yarn breakage during weaving, prevent or decrease hairiness, reduce electrostatic problems, and be easily removed during desizing (Cai et al. 2003). Although starch and starch derivatives meet most of these requirements for cotton yarns, starch sizes do not provide good performance during weaving for synthetic fibers and their blends and are sometimes difficult to be desized when used on tightly woven fabrics. PVA is a preferred sizing agent for synthetic fibers and their blends due to its excellent properties such as film strength, flexibility and adhesiveness, and water solubility, which makes it easier to be desized.

Although sizing is an inevitable process and offers substantial benefits during weaving, there are several problems associated with sizing. Sizing and desizing contribute significantly to the effluents generated in a textile plant and are reported to be responsible for about $50-80 \%$ of the chemical oxygen demand (COD) in textile waste water (Gartiser et al. 1998). Starch-based sizes are reported to have a COD and biochemical oxygen demand (BOD) in the range of 900-1,200 and 500$600 \mathrm{mg} \mathrm{O}_{2} / \mathrm{g}$, whereas PVA has a COD of $1,700 \mathrm{mg}$ $\mathrm{O}_{2} / \mathrm{g}$ and a BOD of $30-80 \mathrm{mg} \mathrm{O}_{2} / \mathrm{g}$. Similarly, polyacrylates have a COD of $1,350-1,650 \mathrm{mg} \mathrm{O} / \mathrm{g}$ but low BOD of $50 \mathrm{mg} \mathrm{O}_{2} / \mathrm{g}$. It is estimated that $1 \mathrm{~g}$ of PVA generates $0.016 \mathrm{~g}$ 5-day $\mathrm{BOD}\left(\mathrm{BOD}_{5}\right)$ or $1.6 \mathrm{~g}$ COD which means a low $\mathrm{BOD}_{5}$ to $\mathrm{COD}$ ratio indicating the poor degradability of PVA (Goswami et al. 2004; Lin and Lan 1993). It is reported that only about $60 \%$ of PVA was degraded after 4 months of incubation under anaerobic conditions and $0-12 \%$ of PVA was degraded in anaerobic sludge after 77 days (Liu et al. 2010). The low BOD of the synthetic sizes is a concern, and efforts have been made to replace the synthetic sizes with biodegradable sizes (Matos et al. 2011).

Chemical and physical modification of starch is the most common approach used to develop biodegradable sizes for synthetic fibers and their blends (Mohamed et al. 2010). Efforts have also been made to recover PVA and avoid release into the effluent and also to develop methods to increase the degradation of PVA (Moreau 1981; Moreland 1980). Special microorganisms, combination of chemical and biological treatments, and modification to anaerobic reactors have been done to improve the biodegradability of PVA (Narayana 1993; Opwis et al. 1999; Ramesh Babu et al. 2007). Attempts have also been made to eliminate the need for sizing (Ramesh Babu et al. 2007). Unfortunately, most of these attempts have been unsuccessful, and currently, there are no sizing agents that can provide the desired sizing properties, biodegradability, and cost-effective substitute to PVA for sizing synthetic fibers and their blends.

One of the major criteria in evaluating a sizing chemical is the ability to form film and have good adhesion to the substrate. Plant proteins such as soy proteins, wheat gluten, and zein have been extensively studied as films for food packing and other applications. Plant proteins have been made into fibers and nano- and microparticles and have also been used as matrix for composites (Reddy and Yang 2011a, b; Rongrong et al. 2011; Xu et al. 2011). Plant proteins are also available in large quantities at low cost and are easily biodegradable. These properties make plant proteins ideal candidates as sizing chemicals. However, there are no reports on using plant proteins for sizing. In this research, we have used soy proteins to size polyester and polyester/cotton rovings, yarns, and fabrics. The effect of sizing conditions on the properties of the sized materials and the biodegradability of the soy protein size has been studied in comparison to commercially available PVA-based sizes.

\section{Experimental}

\section{Materials}

Soy proteins (PRO-FAM 646) were provided by ADM International, Decatur, IL, USA. The polyester/cotton $(65 / 35)$ rovings (70s Hank) and yarns $(15 \mathrm{Ne})$ used in the study were supplied by Mount Vernon Mills. The polyester (Nan Ya, Lake City, SC) used in the blend was of 1.4 denier, 1.5-in. cut length with breaking tenacity of $6.5 \mathrm{~g} /$ denier and elongation of $27.8 \%$. The cotton used in the polyester/cotton blend was Southeastern cotton (strict low middling) with an average length of $27 \mathrm{~mm}$ and a micronaire of 5 . The $100 \%$ polyester rovings and yarns were supplied by Shuford Yarns LLC, Hickory, NC, USA. The fabrics used (polyester/cotton (P/C) type 7435 and $100 \%$ polyester type Dacron 54) were purchased from Testfabrics Inc., West Pittston, PA, USA. PVA-based commercially available sizes supplied by major sizing chemical manufacturers in the USA were used to compare the sizing performance of the proteins. All other chemicals used were purchased from VWR International.

\section{Sizing}

Soy proteins $(0.25$ to $2 \%)$ were pretreated in alkaline solutions at a preset temperature for a predetermined 
time. The pretreatment conditions such as concentration of alkali (0.01 to $0.1 \%)$, time, and temperature $\left(20-90{ }^{\circ} \mathrm{C}\right)$ were varied to study the effect of soy protein pretreatment conditions on sizing performance and to identify the optimum conditions for preparing the size. After the pretreatment, the protein solution was adjusted to the desired $\mathrm{pH}$ (7-10). Samples (rovings, yarns, or fabrics) were treated (immersed) in the sizing solution at $90{ }^{\circ} \mathrm{C}$ for $5 \mathrm{~min}$. The rovings and yarns were wound onto a frame to have adequate tension and immersed in the sizing solution. In the case of fabrics, the sizing solution was padded onto the fabrics ensuring that a constant pickup was obtained. The commercial PVA sizes were applied on to the rovings, yarns, and fabrics using the manufacturer-recommended conditions. After sizing, the materials were conditioned at $21{ }^{\circ} \mathrm{C}$ and $65 \%$ relative humidity for about $24 \mathrm{~h}$ before testing. The amount of size (percent size add-on) on the rovings, yarns, and fabrics was determined by weighting oven-dried $\left(105^{\circ} \mathrm{C}\right)$ samples before and after sizing.

\section{Characterization}

\section{Viscosity}

Viscosity of the sizing solution was measured in a rheometer (Brookfield, model R/S Plus) using different concentrations and temperatures of sizing solutions. A CC-48 cup and about $70 \mathrm{~g}$ of solution was used for each test. The spindle and cup were immersed in a water bath to ensure that a constant temperature was maintained throughout the study. Viscosity was recorded in terms of millipascal-second.

\section{Tensile properties}

The sized rovings were tested to determine their tensile strength and elongation as an indication of cohesiveness of the soy proteins to the fibers in the rovings. Testing was performed on a MTS tensile tester (model: QTest 10) using a gauge length of $10 \mathrm{~cm}$ and a crosshead speed of $50 \mathrm{~mm} / \mathrm{min}$. Yarns were tested on an Instron tensile tester (model 5555) using a gauge length of $10 \mathrm{~cm}$ and a crosshead speed of $18 \mathrm{~mm} / \mathrm{min}$. At least 20 tests were conducted for each sizing condition, and each experimental condition was repeated at least three times.

\section{Abrasion resistance}

Abrasion resistance was determined on both yarns and fabrics. Yarn abrasion tests were conducted on a cohesion tester (model Y 731D; Changzhou Huafang Textile Instrument Co., Ltd., Changzhou, China). In this tester, yarns were wrapped around pins to create adequate tension and rubbed on top to simulate the frictional forces experienced during weaving. The number of cycles required to break the yarns was recorded. The higher the number of cycles required to break the yarns, the higher was the resistance to abrasion. Fabrics were tested for the changes in abrasion resistance on a Universal Wear Tester using " 0 " grade emery paper and 1-lb weight for the polyester fabrics and 0.5-lb weight for the $\mathrm{P} / \mathrm{C}$ fabrics. The number of cycles required to create a hole in the fabric was used as an indication of the abrasion resistance.

\section{Desizing}

The sized fabrics with a known amount of percent addon were desized to determine the efficiency of removal of the soy proteins and PVA from the fabrics. Desizing was performed by treating the sized fabrics in various ratios of water to fabric at different temperatures and for different times. After treatment, the fabrics were rinsed in cold/warm water and then dried. The fabrics were weighed before and after desizing and the loss in weight was calculated to determine the desizing efficiency.

\section{Biodegradation}

\section{$C O D$ and $B O D$}

Biodegradation of the sizing solutions was determined in terms of $\mathrm{COD}, \mathrm{BOD}_{5}$, and changes in total nitrogen and ammonia nitrogen. To determine the biodegradation of the sizing solutions, waste water sludge from the local waste water treatment plant was used. The sludge was first diluted and then aerated in the laboratory for 2 days to acclimatize the microorganisms. The sizing solutions were added into the sludge at a concentration of $300 \mathrm{ppm}$. Based on the normal percent add-on after sizing and the amount of water consumed for sizing, desizing, and other finishing operations, the typical concentrations on size in a textile waste water treatment plant will be about 100-150 ppm. A higher concentration (300 ppm) was deliberately chosen to understand the effect of proteins on biodegradability. Protein samples were aerated with the sludge for up to 6 days. At the desired treatment time, the sludge solution was collected and centrifuged to remove the solids. The top liquid layer was collected to analyze for the $\mathrm{COD}, \mathrm{BOD}_{5}$, and total and ammonia nitrogen. COD tests were conducted according to the United States Environmental Protection Agency method 8000 . A high-range $(20-1,500 \mathrm{mg} / \mathrm{L})$ COD test kit (TNT 822) was purchased from Hach Company and used for the study.

The 5-day BOD test was performed according to the Standard Methods for the Examination of Water and Waste Water published by the American Public Health Association. The oxygen levels in the water with and without sludge and before and after treatment were measured using a dissolved oxygen probe (Hach Company, 
HQ 440D multi). Samples were appropriately seeded and the water used for the test confirmed to the standard and had an oxygen depletion of less than $0.2 \mathrm{mg} / \mathrm{L}$ in 5 days.

\section{Total and ammonia nitrogen}

The total nitrogen in the sludge was calculated based on the alkaline persulfate oxidation digestion method and ammonia nitrogen was calculated using salicylate and hypochlorite in an alkaline phosphate buffer. The buffer turns the effluent water into green color and the intensity of the color being proportional to the amount of ammonia in the sample. To determine the ammonia nitrogen, the sample was added with salicylic acid $(50 \mathrm{~g} / \mathrm{L})$, potassium sodium tartrate $(50 \mathrm{~g} / \mathrm{L})$, sodium nitroferricyanide $(10 \mathrm{~g} / \mathrm{L})$, and sodium hypochlorite solution ( $3.5 \mathrm{~g} / \mathrm{L}$ active chlorine). The mixture was allowed to stand for $1 \mathrm{~h}$ at room temperature. The samples were later measured with a spectrophotometer (Beckman Coulter: model DU 720) for absorbance at $697 \mathrm{~nm}$ using a cuvette. A calibration curve prepared with known concentrations of ammonia was used to determine the ammonia in the samples.

Total nitrogen was determined by adding potassium persulfate into the sample and digesting the mixture at $120^{\circ} \mathrm{C}$ for $40 \mathrm{~min}$. After digestion, $1 \mathrm{~mL} \mathrm{HCl}$ was added to terminate the digestion. The total nitrogen was determined by measuring the absorbance at 220 and $275 \mathrm{~nm}$ for the blank (distilled water) and the sample with size, respectively. The concentration of total nitrogen was calculated using calibration curves that had $R^{2}>0.999$.

\section{Film preparation and properties}

Films were prepared from soy proteins and PVA for comparison. Soy proteins (6\%) were heated in $\mathrm{pH} 12$ water at $90{ }^{\circ} \mathrm{C}$ for $30 \mathrm{~min}$. After heating, the solution was cast on Teflon-coated glass plates and allowed to dry at $21{ }^{\circ} \mathrm{C}$ and $65 \%$ relative humidity. Films were conditioned for $35-40 \mathrm{~h}$ and collected. To prepare PVA films, $6 \%$ PVA was heated in water to $90{ }^{\circ} \mathrm{C}$ and held for $30 \mathrm{~min}$. PVA solution was also cast on glass plates and the films formed were collected after evaporating water and conditioning under standard conditions. Tensile properties of the films were tested according to ASTM D822 with an MTS (QTest 10) tensile tester using a gauge length of $2 \mathrm{in}$. and a traverse speed of $10 \mathrm{~mm} /$ min. At least 20 samples obtained from two to three films cast separately were tested and the average and standard deviation are reported.

\section{Statistical analysis}

Data generated were analyzed by Tukey's multiple pairwise comparisons using SAS software (SAS institute Inc., Cary, NC, USA). Statistical significance was considered if the $p$ value was $<0.05$.

\section{Results and discussion}

Effect of size pretreatment conditions on tensile properties

The effect of increasing alkali concentration from 0.01 to $0.1 \%$ on the tensile strength and elongation of polyester and polyester/cotton rovings is shown in Figure 1. Strength of the $\mathrm{P} / \mathrm{C}$ and polyester roving was significantly higher when a low concentration (0.01 and $0.03 \%)$ of alkali was used. At the highest alkali concentration $(0.1 \%)$, the strength was considerably lower for both the polyester (38 \% lower) and P/C (39\% lower) rovings compared to their respective strength at $0.01 \%$ alkali, but there was no significant decrease in the strength or elongation when the alkali concentration was 0.05 or $0.08 \%$. The $\mathrm{P} / \mathrm{C}$ rovings had higher strength but lower elongation than the polyester roving due to the large size (diameter) of the $\mathrm{P} / \mathrm{C}$ roving and inherent property differences between cotton and polyester, especially elongation. Pretreating the soy proteins at high alkali concentrations hydrolyzed the proteins and therefore decreased the tensile strength with an increasing concentration of alkali. Treating with different concentrations of alkali also changed the viscosity which affects the size penetration and therefore the performance properties (Saravanan et al. 2009). Soy proteins (1\%) had lower viscosity $1.5 \mathrm{mPa}$ s compared to $2.0 \mathrm{mPa}$ s for PVA that would enable better penetration of soy protein into the roving. The viscosity of the soy protein solutions developed in this research is within the range reported for commonly used sizing agents (Cacho 1980).

Varying the pretreatment time between 20 and $40 \mathrm{~min}$ did not show any major effect on the strength or elongation as seen in Figure 2, except for the P/C rovings which had a slightly lower $(11 \%)$ strength when pretreated for $40 \mathrm{~min}$. Although longer pretreatment time will hydrolyze the proteins resulting in lower strength and elongation, the range of pretreatment times studied in the research were considerably narrow, and therefore, there was no significant change in the tensile properties with an increasing pretreatment time.

A study of sizing at room temperature $\left(20^{\circ} \mathrm{C}\right)$ and at $90{ }^{\circ} \mathrm{C}$ showed considerable changes in terms of strength and elongation of the roving as seen in Figure 3. Strength of polyester and $\mathrm{P} / \mathrm{C}$ roving and elongation of the polyester roving were much higher when sized at $90{ }^{\circ} \mathrm{C}$ compared to sizing at $20^{\circ} \mathrm{C}$, whereas no change was observed in the elongation of the $\mathrm{P} / \mathrm{C}$ roving when sized at the two temperatures. Higher temperatures enable the protein size to penetrate into the fibers and bind the fibers together leading to higher strength and elongation. Attempts are being made to reduce energy consumption in textile mills by sizing at room temperature instead of the traditional high-temperature $\left(85-95^{\circ} \mathrm{C}\right)$ sizing (Sawhney et al. 2005). The performance of coldsized yarn was reported to be similar to that of yarns 


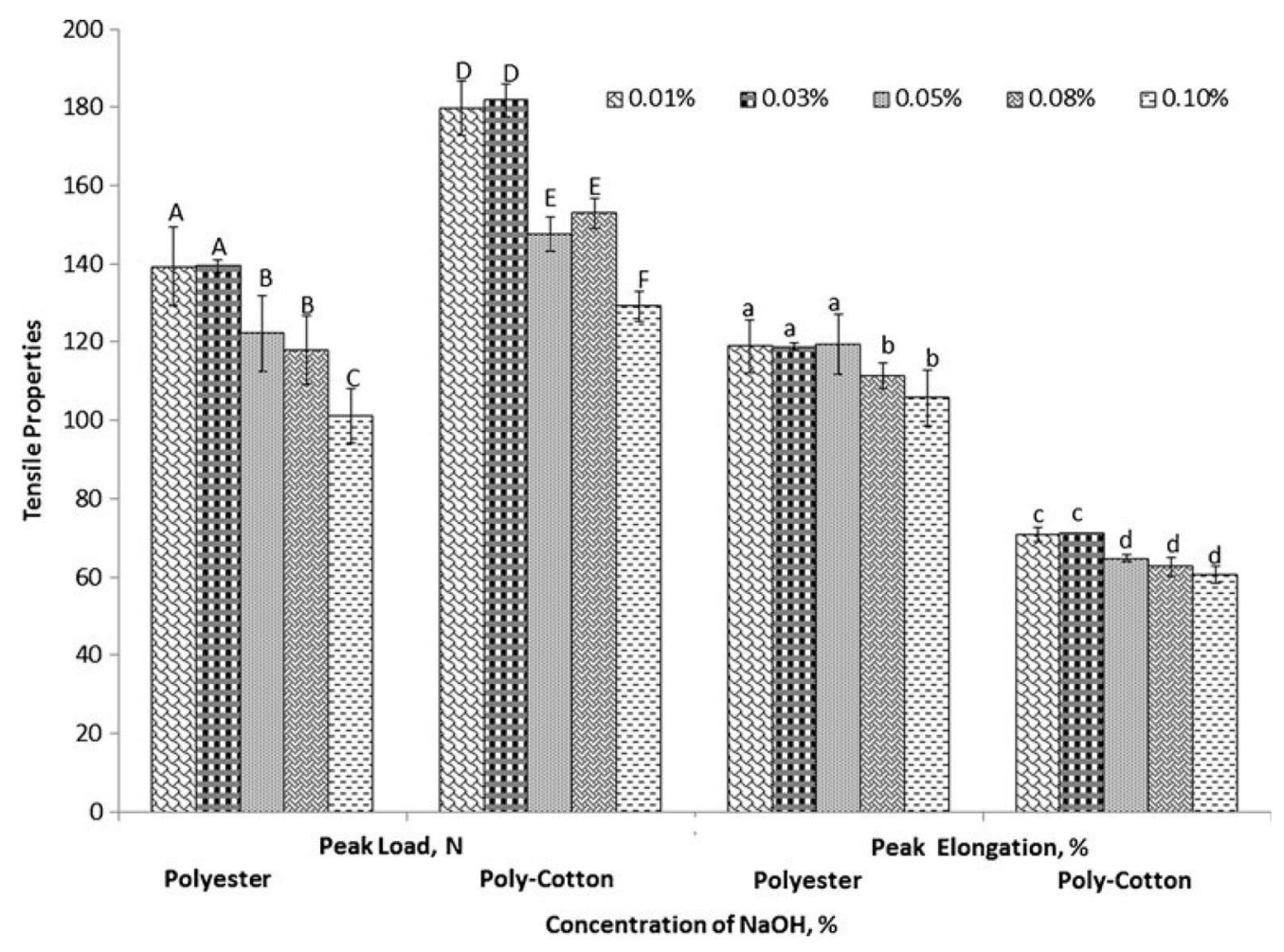

Figure 1. Influence of concentration of sodium hydroxide used during pretreatment of soy protein on the tensile properties of polyester and $\mathrm{P} / \mathrm{C}$ roving at similar percent addon $(5 \%)$. Soy protein $(1 \%)$ was pretreated at $90^{\circ} \mathrm{C}$ for $30 \mathrm{~min}$. For each property, data point with different letters indicates statistically significant difference.

sized at high temperatures. Although the properties of the rovings sized at $20^{\circ} \mathrm{C}$ were lower than those sized at $90^{\circ} \mathrm{C}$, the strength improvement provided by the soy protein size after sizing at $20^{\circ} \mathrm{C}$ is probably adequate to protect the yarns during weaving.

Changing the $\mathrm{pH}$ of the sizing solution from 7 to 10 affected the tensile strength of the $\mathrm{P} / \mathrm{C}$ roving but did not show any major influence on the polyester rovings as seen in Figure 4. At pH 7, the peak load of the P/C roving was about $112 \mathrm{~N}$ compared to $150 \mathrm{~N}$ at $\mathrm{pH} 8$. A slight increase in elongation was observed at $\mathrm{pH} 9$ for polyester and at $\mathrm{pH} 8$ for $\mathrm{P} / \mathrm{C}$ roving. Considerable de- crease in strength of the $\mathrm{P} / \mathrm{C}$ roving was observed when sizing was done at $\mathrm{pH}$ values 9 and 10 . Variations in the strength of the roving at different $\mathrm{pH}$ values should mainly be due to the differences in attraction/repulsion between the proteins and fibers at the different $\mathrm{pH}$ values. Overall, the optimum sizing conditions obtained in this research are typical sizing conditions used in the textile industry. The ability of the soy proteins to provide a good improvement in strength and elongation to the rovings under a range of size preparation conditions indicates that soy proteins could be used for sizing under varying conditions at textile plants.

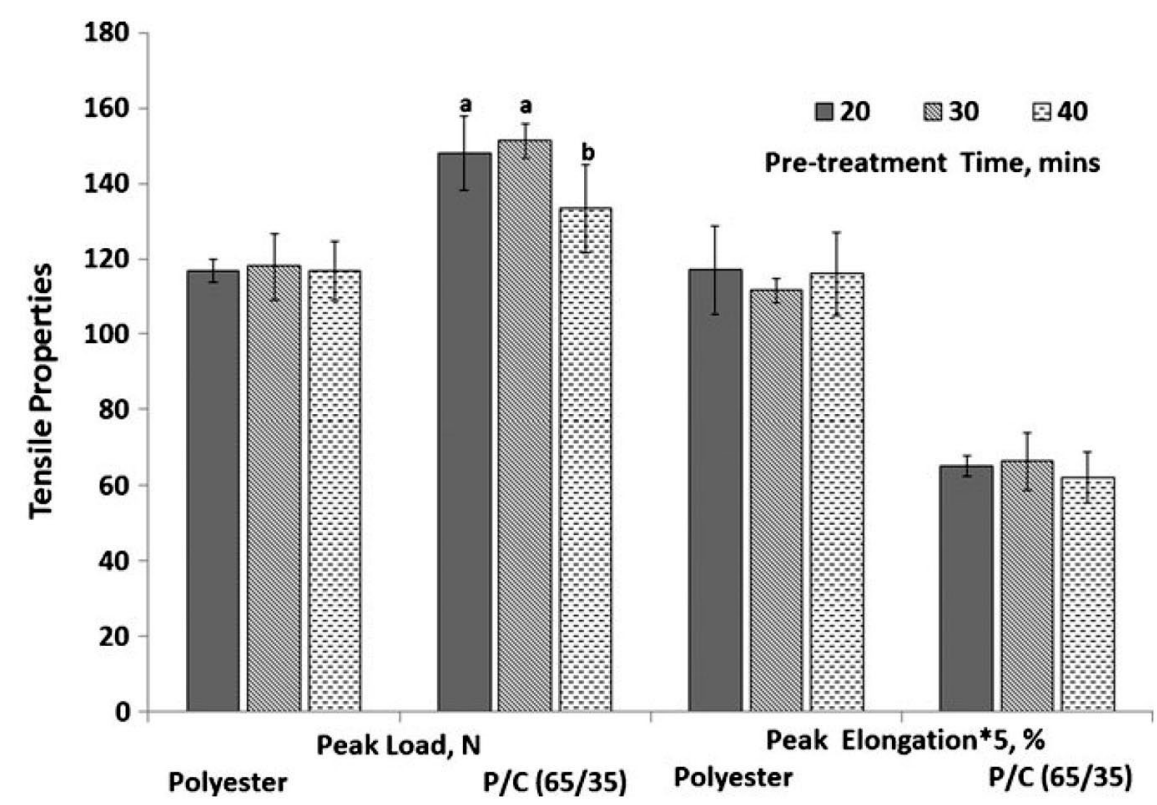

Figure 2. Influence of pretreatment time on the tensile properties of polyester and $\mathrm{P} / \mathrm{C}$ roving treated with $1 \%$ soy protein at $90^{\circ} \mathrm{C}$ and $\mathrm{pH} 8$ with a percent add-on of about $5 \%$. Statistical differences in pretreatment time, if any, for each property is indicated with different letters. 


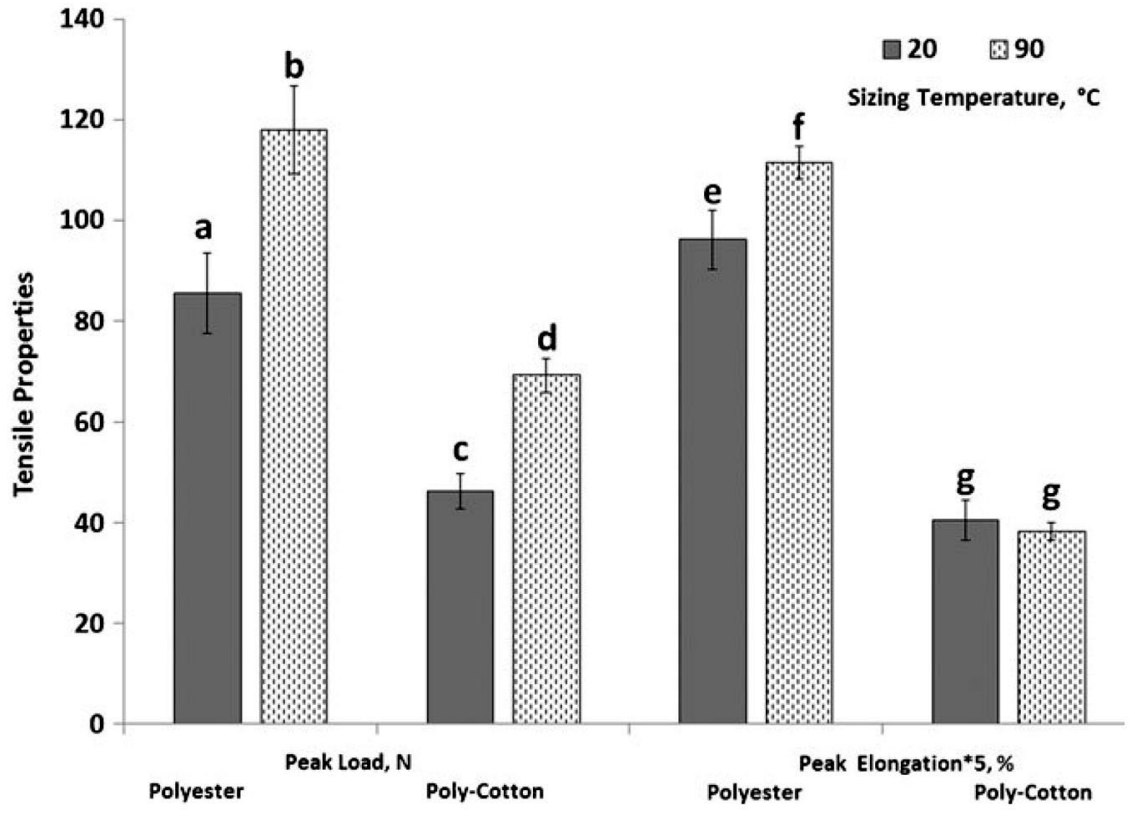

Figure 3. Effect of sizing temperature on the tensile properties of polyester and $\mathrm{P} / \mathrm{C}$ roving sized with soy proteins and having $5 \%$ add-on. The size was pretreated at $90^{\circ} \mathrm{C}$ for $30 \mathrm{~min}$. For each property, data point with different letters indicates statistically significant difference
Effect of percent add-on on sizing performance

The performance of a size is directly related to the amount of size added onto the materials. Generally, increasing the amount of size up to an optimum level should increase the performance properties. As seen in Figure 5, increasing the concentration of soy protein size continually increased the strength of both the polyester and $\mathrm{P} / \mathrm{C}$ rovings. Rovings sized with PVA also showed a continual increase in strength with increasing percent add-on but the percent change was considerably lower. At the lowest percent add-on of about $2 \%$, the $\mathrm{P} / \mathrm{C}$ and polyester rovings sized with soy proteins had strength of 108 and $83 \mathrm{~N}$, respectively, compared to $168 \mathrm{~N}$ for PVA. Further increase in percent add-on did not show a major improvement in strength for the rovings sized with PVA but the strength of the roving sized with soy proteins increased. At about $12 \%$ add-on, the polyester and $\mathrm{P} / \mathrm{C}$ roving sized with soy proteins had strength of 196 and $231 \mathrm{~N}$, respectively, very similar to the strength of the rovings sized by PVA. However, a much higher percent add-on (12-13\%) was necessary for the soy protein size to provide strength comparable to PVA (6-7 \% add-on).

It should be noted that in addition to the primary ingredient PVA, size contains several additives such as plasticizers, emulsifying agents, and others that will improve the adhesion and performance properties of the sized materials. The addition of such additives could also make the soy proteins provide better performance

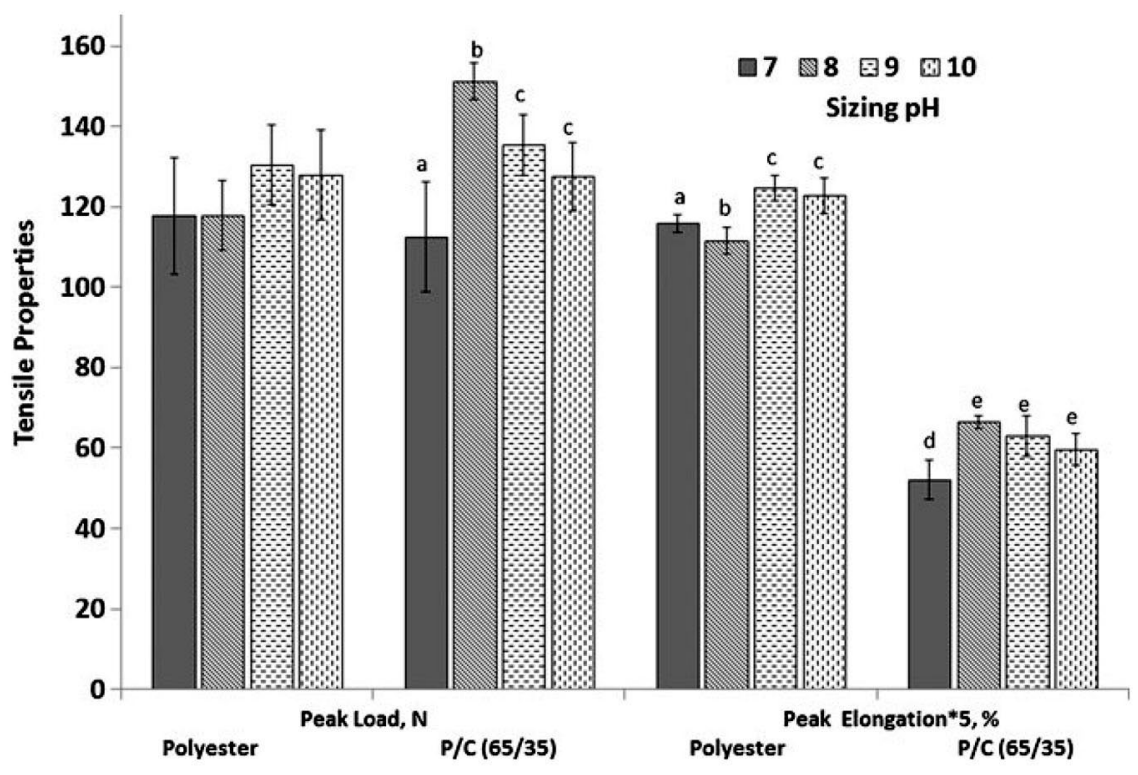

Figure 4. Effect of sizing $\mathrm{pH}$ on the tensile properties of polyester and $\mathrm{P} / \mathrm{C}$ roving treated with $1 \%$ soy protein that was pretreated at $90^{\circ} \mathrm{C}$ for $30 \mathrm{~min}$. For each property, data point with different letters indicates statistically significant difference. 


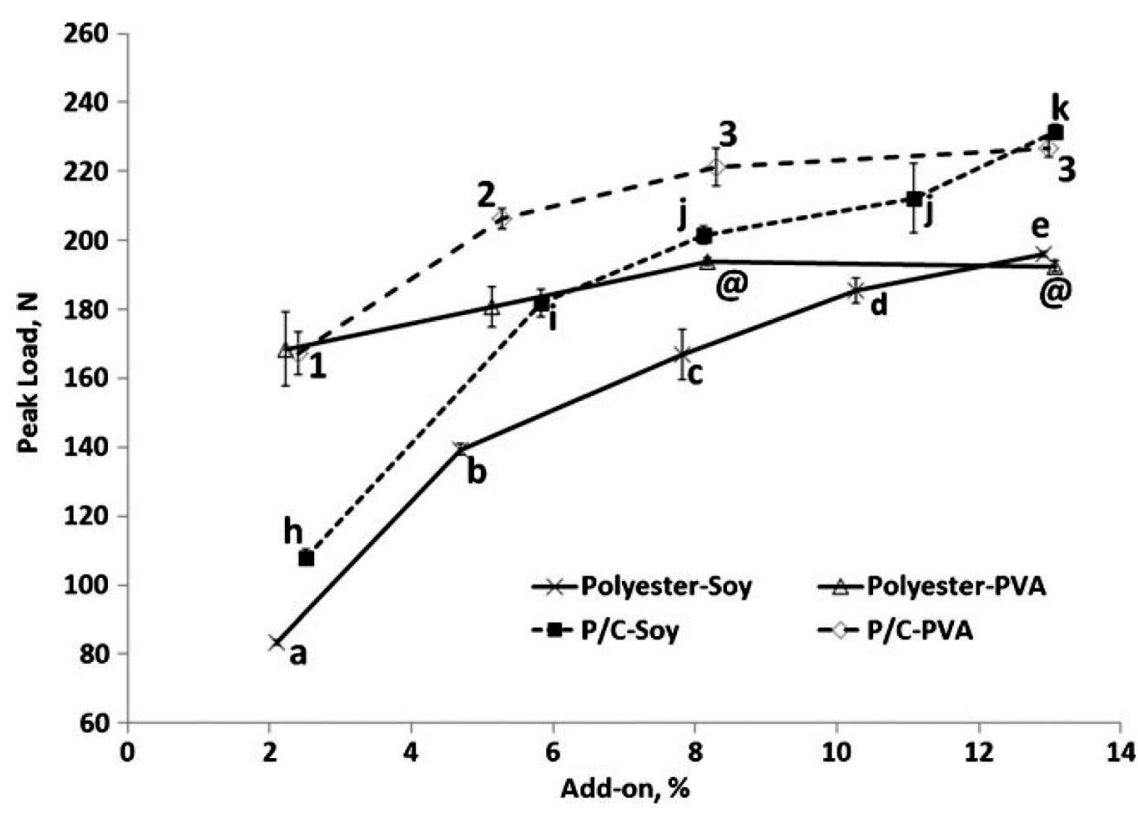

Figure 5. Influence of percent size addon on the tensile properties of polyester and $\mathrm{P} / \mathrm{C}$ roving treated with $1 \%$ soy protein that was pretreated for $30 \mathrm{~min}$ at $90^{\circ} \mathrm{C}$. PVA and soy protein sizing was done at $90^{\circ} \mathrm{C}$ for $5 \mathrm{~min}$. On each curve, data points with different letters, numbers, or symbols indicate statistically significant difference. at lower percent add-on. Also, PVA films had much higher breaking stress $(24.3 \pm 3.9 \mathrm{MPa})$ and elongation $(278 \pm 34 \%)$ compared to $1.6 \pm 0.2 \mathrm{MPa}$ and $1.9 \pm 0.3 \%$ for soy proteins, which also contributes to the higher strength of the rovings treated with PVA. The ability of soy proteins to provide similar performance to PVA despite the films having relatively low strength and elongation should mainly be due to the better affinity between the proteins and the fibers.

Performance of sized materials at different relative humidities

During weaving, the humidity of a weaving room varies between 55 and $80 \%$ and it is important that the size provides adequate protection to the yarns at different humidities. As seen in Figure 6a, the peak load of both the polyester and $\mathrm{P} / \mathrm{C}$ rovings is significantly lower at $55 \%$ humidity compared to their respective properties at 65 and $75 \%$ humidity. At low humidity, the protein film on the rovings is probably less flexible, and therefore, we see a decrease in strength and elongation. Also, the higher moisture at high humidities acts as lubrication and improves the strength and elongation. However, most modern weaving rooms operate at $65-70 \%$ humidity at which the soy protein sizes show good performance. The effect of humidity was more pronounced on $\mathrm{P} / \mathrm{C}$ because cotton absorbs more moisture than polyester at higher humidities. Both the polyester and $\mathrm{P} / \mathrm{C}$ rovings sized with $\mathrm{PVA}$ were relatively unaffected by humidity as seen in Figure 6b. A slight increase in strength for the $\mathrm{P} / \mathrm{C}$ rovings and elongation of the polyester rovings was observed at 65 and $75 \%$ humidity compare to the properties at $55 \%$ humidity. As with
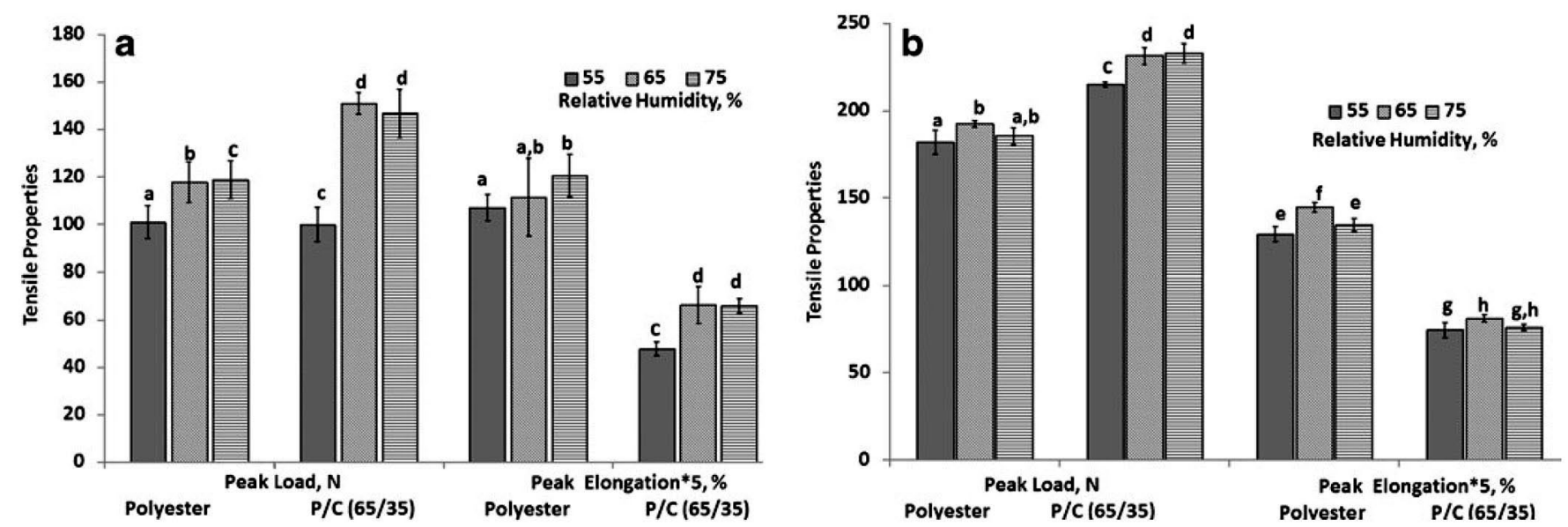

Figure 6. Influence of percent relative humidity on the tensile properties of polyester and P/C rovings treated with $1 \%$ soy protein that was pretreated for $30 \mathrm{~min}$ at $90^{\circ} \mathrm{C}$ (a) compared to the changes in tensile properties for rovings treated with PVA (b). Soy protein sizing was done at $90^{\circ} \mathrm{C}$ for $5 \mathrm{~min}$. For each property, data point with the different letters indicates statistically significant difference 


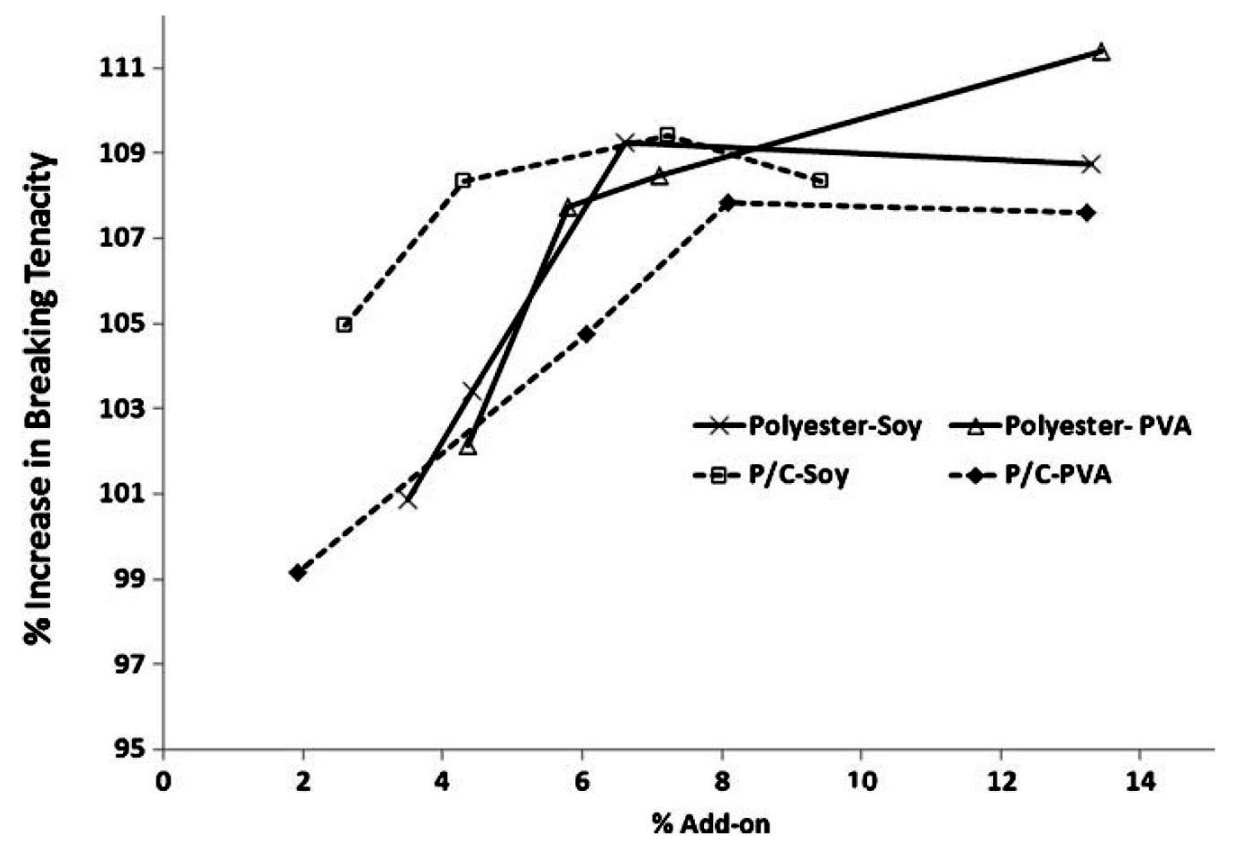

Figure 7. Changes in the breaking tenacity of $\mathrm{P} / \mathrm{C}$ and polyester yarns sized with soy proteins and PVA at different percent add-on. the proteins, lower humidity (55\%) should decrease the moisture on PVA, make the film brittle, and therefore decrease the strength and elongation.

Tensile properties of sized yarns

Sized yarns are expected to show an increase in tensile strength between 15 and $25 \%$ depending on the count and type of yarns (Schonberger et al. 1997). Figure 7 shows that there was a marginal increase (5-12\%) in strength of the yarns after sizing with soy proteins and PVA. P/C yarns sized with soy protein showed a higher increase in strength than the yarns sized with PVA at low percent add-on. Increasing the percent add-on on $\mathrm{P} / \mathrm{C}$ yarns increased the strength up to about $8 \%$ addon and the strength increase stabilized at higher percent add-ons. For polyester yarns, the strength increased continually with increasing percent add-on and the soy protein- and PVA-sized yarns showed a similar strength improvement at the different percent add-ons studied.

\section{Abrasion resistance}

Providing adequate protection to the yarns against the abrasive weaving actions is one of the most important properties of a sizing material. The resistance to abrasion was evaluated using both yarns and fabrics. After yarn abrasion tests, polyester yarns sized with soy proteins had considerably lower abrasion resistance (46 cycles) compared to 84 cycles for PVA. P/C yarns sized with soy protein showed slightly lower (62 cycles) compared to PVA (77 cycles). This result was different than the roving study where both the $\mathrm{P} / \mathrm{C}$ and polyester roving showed a similar or better improvement in tensile prop- erties compared to the rovings sized with PVA. However, the sized yarns, especially $\mathrm{P} / \mathrm{C}$ yarns, had considerably higher abrasion resistance than the unsized yarns demonstrating the protective nature of the size.

Fabric abrasion showed (Figure 8) the higher resistance of the soy protein-sized materials for polyester, whereas $\mathrm{P} / \mathrm{C}$ fabrics sized with soy proteins had considerably lower abrasion resistance than PVA at all percent add-ons studied. At $3 \%$ add-on, polyester fabrics sized with soy proteins had a much higher abrasion resistance of 272 cycles compared to 186 cycles for fabrics sized with PVA. For P/C fabrics, the PVA size provided higher abrasion resistance (126 cycles) compared to soy proteins ( 89 cycles). This result is contrary to the roving strength increase where the $\mathrm{P} / \mathrm{C}$ rovings showed a much higher improvement in strength than the polyester rovings sized with soy proteins. Roving strength increase is predominantly influenced by cohesion between fibers, whereas abrasion resistance is mostly related to the surface film on the fabrics. Soy proteins would have better cohesion for cotton than polyester, and therefore, the $\mathrm{P} / \mathrm{C}$ roving had a higher strength increase than polyester rovings. Repulsion between the hydrophobic polyester and hydrophilic soy proteins probably results in the formation of a denser film on the surface of the polyester fabrics leading to better abrasion resistance of polyester fabrics compared to $\mathrm{P} / \mathrm{C}$ fabrics.

\section{Desizing}

In addition to protecting the warp yarns during weaving, a good sizing material should also be easily removed (desized) from the fabrics. Although PVA is water soluble, desizing PVA requires high temperatures 


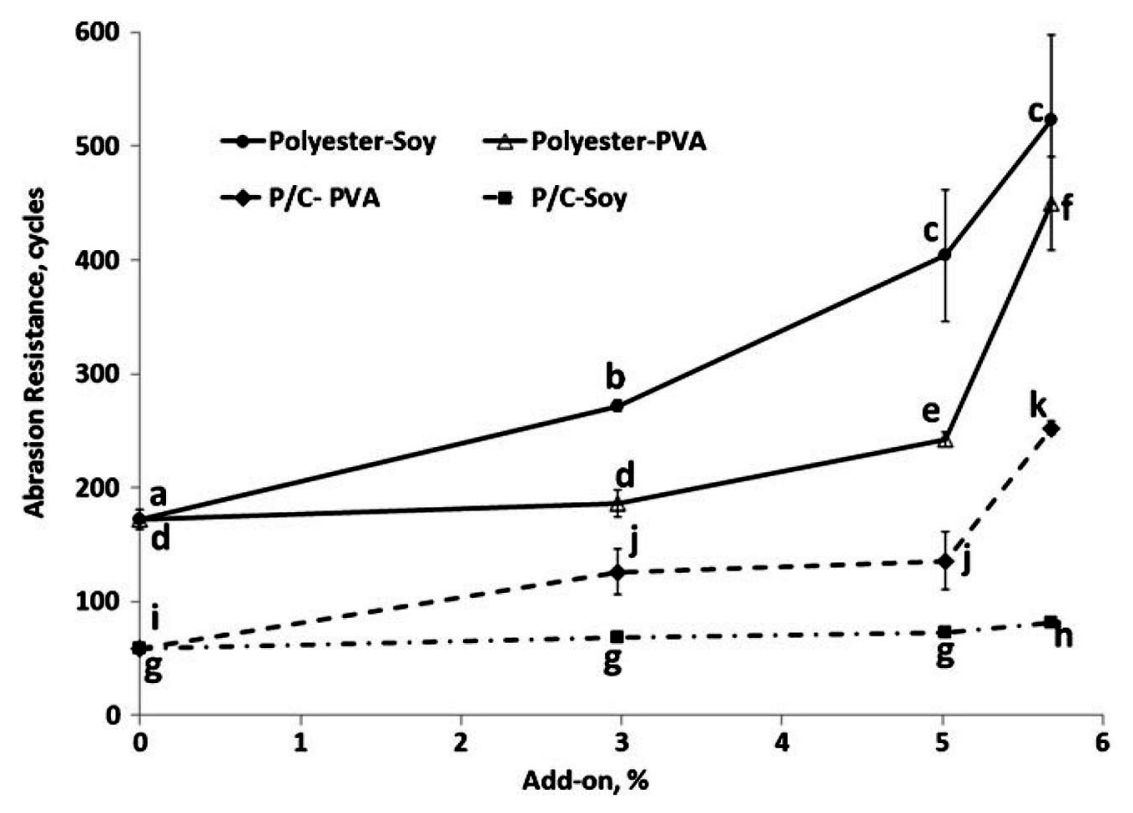

Figure 8. Comparison of the abrasion resistance of polyester and $\mathrm{P} / \mathrm{C}$ fabrics treated with soy protein and PVA at different percent add-on. On each curve, data point with the different letters indicates statistically significant difference. and is normally done at $90{ }^{\circ} \mathrm{C}$ (Sun et al. 2012). As seen in Table 1, desizing even at mild conditions using low water to fabric ratio removes $>95 \%$ of the soy protein size on both the polyester and polyester/cotton fabrics. About $98 \%$ of the size was removed when P/C fabrics were washed with 1:10 ratio of fabric to water at $20^{\circ} \mathrm{C}$ and rinsed once. Under the same conditions, polyester fabrics had lower size removal of $78 \%$. Polyester fabrics were considerably thicker than the P/C fabrics, and therefore, there was less size removal even though soy proteins should have lower affinity to polyester compared to $\mathrm{P} / \mathrm{C}$. Additional rinsing after desizing at $20^{\circ} \mathrm{C}$ could lead to higher percent size removal. Desizing accounts for a major portion (up to $50 \%$ ) of the water effluent in a textile plant and also requires enzymes and other chemicals (Vassallo 2005). The ability to remove the soy protein sizes using low amounts of water even at low temperatures and without any chemicals would mean considerable savings in energy consumption and less water as effluent in textile mills. Higher temperature and fewer rinses or lower temperature but addi- tional rinses could be chosen to obtain the desired level of size removal.

Biodegradation

\section{Chemical oxygen demand}

Figures 9 and 10 depict the biodegradability of the soy protein size compared to PVA-based commercial size from 0 to 7 days of treatment in activated sludge. The soy protein size performed exceptionally well compared to PVA in terms of $\mathrm{COD}, \mathrm{BOD}_{5}$, and nitrogen as seen in Figs. 9 and 10. At 300 ppm, the PVA and soy protein sizes have similar COD values of 542 and $470 \mathrm{mg} / \mathrm{L}$, respectively. However, treating the size solution in activated sludge showed a considerable degradation for soy protein but the COD of the PVA containing sludge did not change appreciably. After 2 days of treatment, the COD of the soy protein-containing sludge decreased to $82 \mathrm{mg} / \mathrm{L}$ from the initial value of $470 \mathrm{mg} / \mathrm{L}$. The PVA-containing sludge did not show any significant decrease in COD.

Table 1. Comparison of the desizeability (percent size removed) for soy protein- and PVA-treated polyester and P/C fabrics at various desizing conditions

\begin{tabular}{|c|c|c|c|c|c|c|c|}
\hline \multirow[t]{3}{*}{ Type of fabrics } & \multicolumn{5}{|c|}{ Desizing conditions } & \multicolumn{2}{|c|}{$\%$ Size removed } \\
\hline & \multirow[t]{2}{*}{ Temp, ${ }^{\circ} \mathrm{C}$} & \multirow[t]{2}{*}{ Time, $\min$} & \multicolumn{2}{|c|}{ Water to fabric ratio } & \multirow[t]{2}{*}{ Rinsing times } & \multirow[b]{2}{*}{ Soy protein } & \multirow[b]{2}{*}{ PVA } \\
\hline & & & Washing & Rinsing & & & \\
\hline \multirow{3}{*}{ Polyester } & & & $5: 1$ & $5: 1$ & 2 & $98.6 \pm 2.4$ & $95.7 \pm 3.8$ \\
\hline & & & $10: 1$ & $5: 1$ & 1 & 100 & $99.4 \pm 1.0$ \\
\hline & 20 & 5 & $10: 1$ & $5: 1$ & 1 & $78.2 \pm 2.1$ & $61.5 \pm 3.4$ \\
\hline \multirow{3}{*}{$\mathrm{P} / \mathrm{C}$} & & & $5: 1$ & $5: 1$ & 2 & $98.3 \pm 3.0$ & 100 \\
\hline & & & $10: 1$ & $5: 1$ & 1 & 100 & 100 \\
\hline & 20 & 5 & $10: 1$ & $5: 1$ & 1 & $98.3 \pm 1.8$ & $82.3 \pm 3.9$ \\
\hline
\end{tabular}




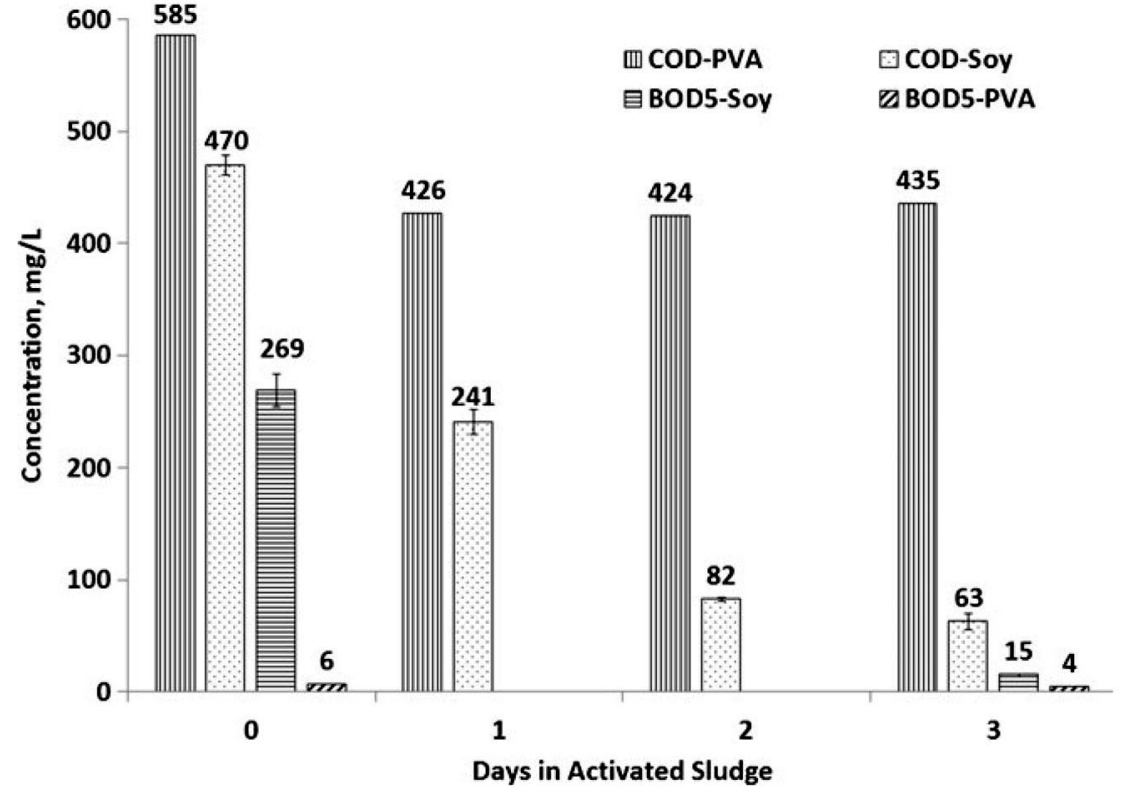

Figure 9. Biodegradation of soy proteins and PVA (300 ppm) in activated sludge in terms of decrease in $\mathrm{COD}$ and $\mathrm{BOD}_{5}$.
Five-day biochemical oxygen demand

The $\mathrm{BOD}_{5}$ for the PVA and soy protein solutions without treating in activated sludge was 19.3 and $14.9 \mathrm{mg} / \mathrm{L}$, respectively. After 3 days of treatment, the $\mathrm{BOD}_{5}$ for the soy proteins decreased to $15 \mathrm{mg} / \mathrm{L}$ whereas the $\mathrm{BOD}_{5}$ for the PVA-containing sludge did not show any appreciable change. The considerable decrease in COD and BOD for the soy protein size after just 3 days of treatment in the activated sludge indicated that the soy proteins could degrade easily in effluent treatment plants. The ratio of $\mathrm{BOD}_{5} / \mathrm{COD}$ for soy proteins was $0.57 \mathrm{com}$ pared to 0.01 at 0 day of treatment suggesting that soy protein contained considerably higher organic material and could be easily degraded in effluent treatment plants (Zhu et al. 2012).

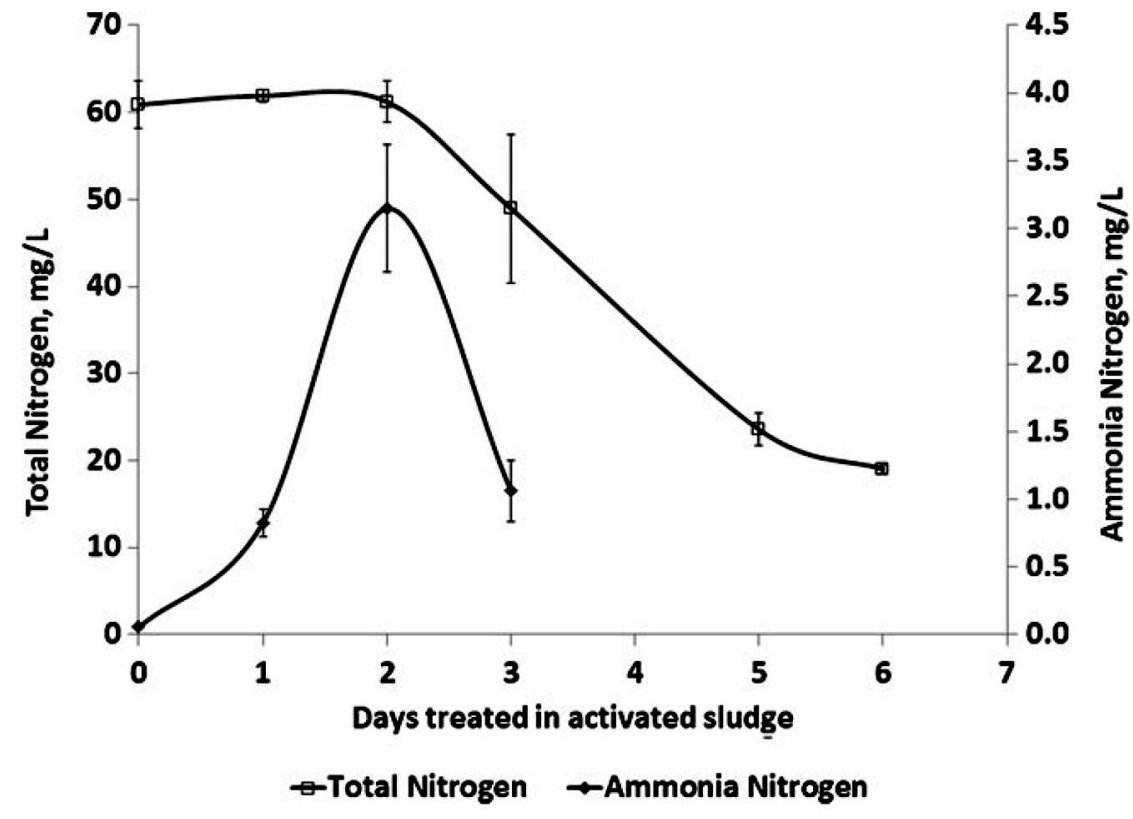

\section{Total and ammonia nitrogen}

The potentially higher amounts of nitrogen that could be released from proteins compared to PVA could be a concern for textile waste water treatment plants. Figure 10 showed that the total nitrogen released from soy proteins was initially $60 \mathrm{mg} / \mathrm{L}$ and continually decreased after treatment in activated sludge. A sharp decrease in total nitrogen and a corresponding increase in ammonia nitrogen were seen after 2 days of treatment indicating substantial degradation of soy proteins. The ammonia nitrogen release sharply decreased at 3 days because most of the soy proteins had already degraded at 2 days and there was negligible ammonia release after 3 days. The low levels of total and ammonia nitrogen released from soy proteins after 3 days of treatment in activated sludge
Figure 10. Degradation of the soy proteins in activated sludge in terms of changes in total and ammonia nitrogen. 
indicated that soy proteins will not adversely impact the operation of the effluent treatment plants.

\section{Conclusions}

Soy protein as a textile sizing agent provided polyester and $\mathrm{P} / \mathrm{C}$ rovings, yarns, and fabrics improved or comparable properties to PVA-based size. Higher (12$13 \%)$ add-on was required for soy protein size to obtain a roving strength improvement comparable to PVA (6-7 \% add-on). Better interaction between soy proteins and cotton compared to polyester provided higher cohesion and therefore higher strength for the $\mathrm{P} / \mathrm{C}$ rovings compared to the strength improvement on polyester rovings. However, soy proteins provided better abrasion resistance on polyester than $\mathrm{P} / \mathrm{C}$ yarns and fabrics. Soy protein-treated fabrics were easily desized (>98\% removal) even with low amounts of water. Unlike PVA, soy proteins were easily biodegradable in activated sludge and the nitrogen in the proteins did not adversely impact the biodegradability. Performance of sized materials, relatively easy biodegradability, and simplicity in preparing the soy protein size are some of the advantages that promote the replacement of PVA with soy proteins for textile warp sizing. Adding sizing ingredients such as plasticizers or chemical modifications to the soy proteins may be necessary to obtain good sizing performance at lower percent add-on for the soy protein-sized materials.

Acknowledgments - Financial support for this work was partially from the Agricultural Research Division at the University of Nebraska-Lincoln, USDA Hatch Act, Multi-State Project S1054 (NEB 37-037) and Chinese National High Technology Research and Development Program 863 Project (2013AA06A307), the Fundamental Research Funds for the Central Universities (Item No. 2011D10543), the Doctoral Dissertation Innovation Program BC201040 of Donghua University, and the China Scholarship Council. We thank Jorge Samayoa and Brad Barber with the Lincoln Waste Water Treatment Facility for their help in the activated sludge studies.

\section{References}

Bisschops I, Spanjers H (2003) Literature review on textile wastewater characterization. Environ Technol 24:1399-1411

Cacho JW (1980) CMC warp sizing vs. polyvinyl alcohol. Text Chem Color 12(4):28-32

Cai Z, Qiu Y, Zhang C, Hwang Y, Marian M (2003) Effect of atmospheric plasma treatment of desizing of PVA on cotton. Text Res J 73(8):670-675

Du G, Liu L, Song Z, Hua Z, Zhu Y, Chen J (2007) Production of polyvinyl alcohol-degrading enzyme with Janthinobacterium sp. and its application in cotton fabric desizing. Biotechnol J 2(6):752-758

Gartiser S, Wallrabenstein M, Stiene G (1998) Assessment of several test methods for the determination of the anaero- bic biodegradability of polymers. J Environ Polym Degrad 6:159-173

Goswami BC, Anandjiwala RD, Hall DM (2004) Textile Sizing. Marcel Dekker, New York

Lin SH, Lan WJ (1993) Ultrafiltration recovery of polyvinyl alcohol from desizing wastewater. J Environ Sci Health A30(7):1377-1386

Liu RR, Tian Q, Yang B, Chen JH (2010) Hybrid anaerobic baffled reactor for treatment of desizing wastewater. Int J Environ Sci Technol 7:111-118

Matos J, Rosales M, Garcia A, Nieto-Delgado C, Rangerl-Mendez JR (2011) Hybrid photoactive materials from municipal sewage sludge for the photocatalytic degradation of methylene blue. Green Chem 13:3431-3439

Mohamed EZ, Amr A, Knittel D, Schollmeyer E (2010) Synthesis and application of new sizing and finishing additives based on carboxymethyl cellulose. Carbohydr Polym 81:769-774

Moreau JP (1981) Polymeric sizing agents for cotton yarns. Text Chem Color 13(12):22-27

Moreland JE (1980) Polyvinyl alcohol warp sizes. Text Chem Color 12(4):21-23

Narayana JHS (1993) Modern trends in the sizing of blended yarns. Indian Text J 103(6):32-36

Opwis K, Knittel D, Kele A, Krefeld ES (1999) Enzymatic recycling of starch-containing desizing liquors. Starch 51(10):348-353

Ramesh Babu B, Parande AK, Raghu S, Kumar TP (2007) Cotton textile processing: waste generation and effluent treatment. J Cotton Sci 11:141-153

Reddy N, Yang Y (2011a) Potential of plant proteins for medical application. Trends Biotechnol 29(10):490-498

Reddy N, Yang Y (2011b) Completely biodegradable soyprotein-jute biocomposites developed using water without any chemicals as plasticizer. Ind Crop Prod 33:35-41

Rongrong L, Xujie L, Qing T, Bo Y, Jihua C (2011) The performance evaluation of hybrid anaerobic baffled reactor for treatment of PVA-containing desizing waste water. Desalination 271:287-294

Saravanan D, Selvakumar R, Velmurugan S, Ramachandran $\mathrm{T}$ (2009) Quality work practices in sizing mills. Text Mag 50(8):38-41

Sawhney APS, Sachinvala ND, Calamari TA (2005) Approaches for reducing or eliminating warp sizing in weaving: an interim report. AATCC Rev 5(9):23-25

Schonberger H, Baumann A, Keller W (1997) Study of microbial degradation of polyvinyl alcohol(PVA) in waste water treatment plants. Am Dyestuff Rep 86(8):9-10

Sun W, Tian J, Chen L, He S, Wang J (2012) Improvement of biodegradability of PVA containing wastewater by ionizing radiation treatment. Environ Sci Pollut Res 19:3178-3184

Vassallo JC (2005) Spun sizing chemicals and their selection. AATCC Rev 5(12):25-28

Xu H, Jiang Q, Reddy N, Yang Y (2011) Hollow nanoparticles from zein for potential medical applications. J Mater Chem 21:18227-18235

Zhu Z, Qiao Z, Zhang L, Hong Y, Wang T (2012) Effects of molecular structure and molar content of acrylate units on aerobic biodegradability of acrylate copolymeric sizing agents. Text Res J 82:889-898. doi: 10.1177/0040517512436825 